New Zealand journal of industrial relations, $1987,12,143-150$

\title{
The Holt narrative and the industrial relations agenda
}

\author{
Tony Simpson*
}

The history of the industrial relations system in New Zealand is the history of dynamic tension between trade unions and employers. That in itself is an unexceptionable statement; it is true of any industrial relations system. It is the source and nature of that dynamic tension which characterises a particular system. In this country that source and nature is often seriously misunderstood. It is depicted by the media (for the obvious reasons associated with their position within the nexus of relationships which make up the dominant consciousness) and by most academic historians (largely implicitly as an inarticulate major premise) as an offensive attempt on the part of the unions to elbow their way into an inappropriate control role within the political and industrial culture and as a defensive response on the part of employer organisations and successive governments to prevent this. The source of this depiction and the reasons for its persistence are interesting but rather outside the scope of this paper although they deserve to be canvassed at some point. Just now I want to suggest an alternative model which I believe to be much more sustainable on the facts.

This is one in which for the past century most industrial relations initiatives have been taken by employers and these have been directed to excluding organisations of workers from the political and industrial consensus. This has been a notion largely unexplored by historians, again for fairly obvious reasons, although to a practitioner in the business such as myself it seems a fairly straightforward conclusion simply on the facts. Equally, like all conclusions, it is a partisan one but of course no less valid for that. I wouldn't see the world in the same way as an employer and they should not expect me to (although strangely enough some of the rowdiest dogfights Ive got into in negotiations from time to time have been over an insistence by employer representatives that there is a single reality and it is the one they can see and no other). I think the Treasury have the same problem at the present time. This process of attack upon unions has been largely supported by the elements which make up the political culture and has only been halted or reversed when such initiatives have transgressed beyond the limits of acceptability imposed by that political culture. Within this context the activities of unions have been largely defensive and have been characterised by an almost pathological craving for respectability as an accepted element in the consensus.

Having said that, of course. I should make it clear that there are many shades and varieties of opinion among both unions, employers and their respective groupings. That's true over time as well as at any point. But it's also more true of unions. One of the things which characterises New Zealand employers is the remarkable congruence, consistency and longevity of their explicit basic agendas. The only thing which seems to change over time as far as they are concerned is the extent of that explicitness. At present they are rather more explicit than is usually the case.

During the past century the trade union movement has, notwithstanding, achieved their object, and then only partially for brief periods between 1890 and 1895 and 1937 to 1949 , and it sometimes seems in spite of rather than because of its best efforts. This is so at odds with the perception of trade unions in the popular imagination that it requires some exigesis. James Holt's Compulsory arbitration in New Zealand: the first forty years provides a framework within which that can be presented. 
This framework is not, however, complete. It seems to me to be missing three crucial elements. The first of these obviously enough is that the book covers the first forty years only. Thus the narrative, although a lucid exposition of the development of the arbitration and conciliation system during that period does not encompass its complete span. Secondly, the book does not clearly enough expound the origins of the system. Instead it seems to have it emerge as if from a crysallis. Finally, the narrative is hermetic in the sense that no consistent pattern of meaning emerges from it which relates it to the broader political scene. This is in terms neither of parallel industrial relations systems which existed and have continued to exist alongside the framework of the Act of 1894 and its successors, nor of the prevailing political culture during the period prior to and during the operations of the Act from 1894 to 1934 or thereabouts. An exploration of these additional dimensions places Holt's narrative in context. In this paper I want to concentrate on the origins of the Act of 1894 because in those origins lies the key to most subsequent developments in the industrial system.

That industrial system as it was introduced in 1894 is based upon certain assumptions concerning the nature of human relationships, in conjunction with a liberal-democratic model of the role of the state in society. These assumptions are basically four. Firstly, that industrial disputes between employers and employees are resolvable and can be resolved by access to conciliation and arbitration machinery by either party but usually in practice by unions which are often the initiators of change and which are usually (although not always) the weaker party. This is what is meant by compulsory arbitration in practice however it may be defined in law (context is usually more definitive than text). This also incorporates the belief that disputes can be prevented in the first place by establishing legal minimum wages and conditions of work.

Secondly, this presumes in its turn that the employees may best act collectively through unions or some other agency and therefore the creation of such rather than being an undesirable conspiracy to invade the natural rights of employers and interrupt the mechanisms of the labour market should be actively encouraged.

Thirdly, that the state representing the community at large should ensure fair play and if either party to the equation is able to tip the balance in its favour then the state should redress it. However, the state has immediately no place in the day to day relations between unions and workers and employers; its role is confined to creating the machinery for the resolution of such disputes as might arise, and ensuring by legislation that certain fundamental protections of workers as to hours, holidays and safety are preserved. The state reserves the right only to intervene directly when there is a perceived clear and present challenge to its authority or to the operation of an essential social service. Such interventions have in fact been relatively rare and have also, at least in my observation or upon my reading. been upon the basis of a false perception of the existence of such a threat. One thinks for instance of the invocation of the Public Safety Conservation Act in 1951 or more recently and to speak of matters in which I have been a direct participant, the several threats by the Muldoon government to derecognise the PSA. I am sure of course that the politicians involved in those instances were perfectly well aware that no such threat existed as that which they conjured up. In the case of the derecognition of the PSA, the bluff was called. The Holland government had rather more success.

Fourthly and underpinning these other presumptions is a belief that this whole activity occurs inside rather than outside the political process. This implies that organisations representing employers and unions should be incorporated in the political consensus as a matter of course. It is important that the significance of this underlying assumption should be clearly grasped. What is meant by the political process and culture should not be confused with the much more restricted compass of the democratic parliamentary system which is only one dimension of it. I am referring to the very much broader and less formal structure through which power is exercised within our society. This means that paradoxically while the introduction for example of industrial arbitration at the instance of single parties distances the industrial relations sphere from the parliamentary process, this brings industrial activity clearly within the broader political consensus and makes it an integral part of the public cultures of power. The four presumptions I have outlined thereby create a place for trade unions within that consensus that they rarely actually enjoy. Equally not all others within that consensus welcome that potential presence as a matter of course.

Consequently the acceptance of these presumptions after 1890 was not a phenomenon conjured out of thin air, nor is 1890 an absolute watershed in that regard. The debate implicit in these assumptions was proceeding prior to that date and is the praxis within which the creation of the 1894 industrial relations legislation is to be understood. Its immediate occasion was the economic and political responses to what has become known to historians and economists as 
the 'Long Depression', the economic decline which persisted in one form or another between 1870 and 1895 .

The economic indicators of this period are sufficiently known and too widely available to require a detailed statement. Briefly rehearsed, the basis of the problem (as always) was a reversal in the terms of trade which disadvantged the New Zealand economy. Although there was a continuous rise in quantity of output, the value of this output declined by about a third per capita during the period. Because the principal exports were wool and wheat and this was reflected in the pattern of large-scale land ownership and the relationship that bore to the banking and finance system, investment capital dried up and there was widespread retrenchment. This, in its turn, entailed unemployment with consequent social distress in a community with no machinery for its alleviation. Statistical information is hard to come by because few adequate statistics were kept, but those which were indicate the results clearly enough. Between 1881 and 1886 the employment ratio of women to men rose from one in seventeen to one in five; wages fell precipitously in some industrial occupations; kours of work increased in some industries to more than ninety a week; and unemployment as a proportion of the total workforce rose (in Christchurch where the total population in 1883 was 15,915 , there were 700 known unemployed at the height of the summer busy season. If the workforce was about $40 \%$ of total population this gives a very rough unemployment rate of $11 \%$ (Sutch, 1966 (a) pp. 58$81)$.

I should perhaps qualify the preceding paragraph by also noting that not all wages fell in the same way. Some categories of skilled workers maintained their rates better than others. A review by Roth for instance of the daily rate for carpenters and joiners between 1876 and 1890 (although it does not take account of length of working day) shows that although there was a fall of $20 \%$ or thereabouts over the period, this was nowhere near as great as for unskilled work. The differential effect of economic depression on various categories of workers is widely remarked; the 1880 s were not materially different from today. The rate paid for any particular occupation is a reflection of the relative scarcity of the workers in question. Unskilled process workers tend to fare worst; others may even improve their position. The relative scarcity of easily accessible figures for a century ago makes definitive comparisons difficult.

The economic response to this period of distress was predictable in a pre-Keynesian age. Such economic troughs were widely considered to be natural phenomena concerning which little could be done; indeed it was believed to be harmful to interfere. Government action should be confined to reducing deficits or as it was more commonly known in that period, balancing the budget. It should be recollected in that connection that the governments immediately subsequent to 1890 were no different to their predecessors. The Liberal group came to power, insofar as they had a national programme at all, committed strongly to retrenchment.

In the event the economy did right itself but this owed little to Liberal fiscal policy (with the possible exception of their rescue of the Bank of New Zealand). We need in considering the period, however, to distinguish carefully between economic and political responses to the long depression. As we are aptly reminded by Sutch: "Before 1870 it was doubtful whether New Zealand would become a viable country; after 1890 the doubt about economic viability was removed but the question of whether the country was worth living in had still to be decided" (1966(b)). The latter aspect of this neat division encompasses the political response.

This occurred at two levels, the parliamentary and the industrial. Some members of the political class, i.e. those who constituted the parliamentary recruiting ground, had by the $1880 \mathrm{~s}$ become thoroughly perturbed by the social consequences of economic turndown. Expressions of concern were not confined to those who were later to be at the centre of what became the Liberal governments. But one of those who did, Robert Stout, will serve as an exemplar of that concern. Stout began as an orthodox Benthamite liberal. He thought the state should not interfere under any circumstances in social or economic matters. Between 1875 and 1890 his views underwent a profound change. By 1886 , for example, he was able to say in a debate over an Eight Hours Bill: "The state must protect those who require protection. If you have strife between labour and capital, which is the stronger of the two? Of course capital is the stronger, and the state must come in and assist labour wherever it can" (Parliamentary Debates, 1856,55, p. 558). He thought that it was up to unions to organise and protect their members as far as possible, but where this failed the government must take a hand. What changed the minds of Stout and many middle-class people like him was the evidence before their eyes of the widespread distress caused by leaving things to take care of themselves. They honestly believed that when they came to a new land they had left behind them such social cankers as industrial and class conflict, economic exploitation, and so forth. The revelations of the Sweating 
Commission which provided only the most dramatic evidence that their presumption was wrong was profoundly shocking to many hitherto complacent middle-class colonists. What they felt is also summed up in a speech by Stout, this time in June 1889: "He confessed that it was with great sadness he saw such a meeting. When he left the old land he had felt as others had - that in coming to a new land he was coming to a country that would be rid of the evils that had tormented the land of his birth; and yet before his colony was fifty years old these troubles were affecting its inhabitants." (Hamer, 1963, p. 93).

Nor were attempts in parliament to mitigate this distress by protective legislation confined to post- 1890 governments. There were unsuccessful Eight Hour Bills in 1885, 1886 and 1889 . There were equally abortive attempts at shop and factory legislation in the latter year. Earlier attempts had been more successful in protecting apprentices and women at least at law. although by the 1880 s these were being widely ignored. In 1882 and 1884 notwithstanding. laws were enacted protecting wages. Most of these attempts had come to grief on the rocks of an intransigent opposition by employers who successfully blocked most efforts to create effective machinery to enforce factory legislation, and who were actually successful in 1885 in having the legal hours of employment extended. ${ }^{1}$ Employers in association with landowners were well-organised in Reform Associations and these took a dim view of attempts to impose limitations on their immediate relations with their employees. Employers had been unable to prevent the setting up of the Sweating Commission in 1889 (although they victimised those who gave evidence in front of it.) (Roth and Hammond, 1981, p. 33). Nor could they stop Hislop. the Minister of Education in the Atkinson government introducing factories, shop, truck, and employer liability legislation in 1890. But they could and did kill this legislation in the Legislative Council, where many employers' friends and representatives lurked both prior to and after 1890 (Sinclair, 1965, pp. 109-111).

The introduction of a Shops and Factories Bill of 1890 stimulated a counterpetition to the Legislative Council signed by 279 manufacturers, shopkeppers and other employers in Canterbury describing the proposal as "altogether unnecessary, harassing, and calculated to injure trade and industry." Among instances of its injurious clauses were cited provisions requiring separate rooms to be set aside for workers to eat their lunches, ("oppressive and impracticable"), and payment for holidays ("a serious tax on manufacturers and employers of labour") (Sutch, 1966(b), p. 75).

Most interesting of all was a private Strikes and Board of Conciliation Bill presented by Downie Stewart, subsequently a prominent member of the anti-Liberal Opposition. This did not pass either, although it was supported by other prominent anti-Liberals such as Russell who led the Opposition against Seddon in the 1890s. All of these initiatives were actuated by the widespread belief that conflict between classes could be, indeed should be, avoided by the creation of arbitration and conciliation machinery and against a backdrop of international debate on the same theme. ${ }^{2}$

The political and industrial response of workers to the distress of the long depression is parallel to but quite distinct from the pattern of middle class parliamentary response delineated above. It was not moreover a specifically trade union response in its most significant manifestation, which was then as now not to combine but to re-emigrate.

In the eight years 1885 to $1889,125,000$ persons left New Zealand, mostly for Australia which was experiencing something of a boom. By 1890 over a thousand people a month were leaving the country. This clearly constitutes an industrial response but has nothing to do with trade unions. Insofar as there was a trade union response, it was reformist not revolutionary. It was almost indeed excessively intent upon its constitutionality. This has been obscured by an obsession by historians with the so-called Maritime Strike in 1890 which is perceived to be the crest of a militant wave and the culmination of the agitation by socialist union organisers over the previous several years. There is hardly an historian who does not accept this frame of reference. Conservative whigs such as Sinclair share common ground with Liberal whigs like Sutch on this at least. Followers of both schools echo their masters' voices. Certainly Holt seems to accept it as a given and it runs as an historiographic theme through the essays on the subject in the recently published Common Cause (1986). In their "The New Zealand Labour Movement 1880-1920" Olssen and Richardson attribute the growth of unionism in the 1880 s to the influence of largely middle-class ideologues. Sinclair in his standard history speaks of the leavening effect of British trade unionists among the Vogel immigrants or as being "imported

(1) For a survey of this legislation prior to 1890 see N S Woods (1963) pp. 17-30.

(2) For an account of this see J Holt (1976). 
from Australia" and building to a climax in 1890. And Sutch characterises the Maritime Council as "a wage earners" revolt" characterised by "discipline and obviously great power". A closer examination reveals, however, that it was nothing of the sort. On the contrary it appears to have been an ill-planned response by a minority of unions to some deliberate provocations by a small number of employers, particularly the Union Steam Ship Company. In at least one of its contributing preludes, a strike of printers against Whitcombe \& Tombs, it was an unexpected byproduct of a trade war between two competing Christchurch printing houses for the available business in a shrinking market. Ironically, one of the parties to this commercial dispute was the Lyttelton Times of which W. Pember Reeves was the editor and which was owned by his family.

A recent interesting article by Erik Olssen has explored the notion that worker militancy is essentially defensive, for the period 1905-11 (Olssen, 1987). This has concluded that the industrial strife usually associated with this period was as much a response to employer attempts to redefine units of work and to depress the rate for each unit as it was an ideological attack on capital or the system of arbitration. By 1911 the attempted defence had been overwhelmed and the events of 1912 and 1913 were a worker response to vengeful provocation by employers. There is evidence to suggest that in a restricted number of industries the same thing was going on in 1889 and 1890. Bollinger's (1968) history of the New Zealand Seamen's Union Against the Wind is a particularly valuable source of information which sustains this interpretation. That is to say workers organised themselves in the Maritime Council to defend their traditional organisation of work but were overwhelmed and confronted by widespread employer victimisation of trade unionists as a result.

One of the difficulties in determining the relative influences of the various trades union groupings in the late eighties and early nineties is the considerable variation in estimates by historians of precisely how many organised workers there were at this period. In 1891 the New Zealand census records that about 58 percent of the occupied males were wage-earners or unemployed. Another estimate calculates that about 41 percent of the population were earners (although not all of course were wage-earners). The whole population was somewhat over half a million. Although there are no specific statistics to tell us how many potentialy might have belonged to trade unions, they cannot have amounted to much less than 150,000 . But how many of them actually belonged to trade unions and to which ones? Most authorities seem to agree that there were relatively few organised workers in New Zealand in the mid to late 1880s. For 1888 the figure is set as low as 3,000 (by Roth, 1973, repeated in Roth and Hammond, 1981) and 5,000 (quoted by Holt from a university thesis of Russell). This seems rather few in relation to the workforce even taking into account the effects on union membership of widespread unemployment (it usually reduces it markedly) and the exclusivity of the composition of most craft unions. During 1889 and 1890 , however, whatever may have been the base figure. membership seems to have expanded spectacularly. Holt cites 7 unions in Auckland in 1889 becoming 34 by late 1890 with a total of 5,000 members. Wood records the formation of 12 new unions in 1890 adding 12,250 to existing unionists for an "estimated total of 20,000 by the end of the year although he does not source this estimate. Roth and Hammond give 20,000 for 1889 rising to double this figure by mid-1890, and for the Maritime Council alone quote Millar, the Council secretary as claiming 63,000 members in October 1890 , although they caution that this is "almost certainly an exaggeration" (1981, p. 34). Campbell in a 1975 article quotes the Lyttelton Times (sympathetic editorially under Reeves to unions) as saying that there were 21,300 unionists in the country of whom 9,000 were in the Maritime Council affiliates (Bollinger in his history of the Seamen's Union says 8,000 at the point of formation and rapid growth thereafter). And Salmond (1950), in a history of the unions at this period cites 3,489 workers in 18 unions affiliated to Trades and Labour Councils in Dunedin in August 1890 and 2,000 members in 8 affiliated unions in Christchurch in December 1889 (later joined by railway and agricultural workers, numbers unspecified). He does not give a national figure nor figures for Wellington or Auckland. Obviously all these estimates cannot be right. Nevertheless they allow some conclusions to be drawn.

Discounting Millar's claim for the Maritime Council, accepting even the most optimistic figures makes it clear that only a fraction of the workforce was unionised, never more than about a fifth and probably much less than that. If the Maritime Council disposed of about a third of organised workers (taking the Lyttelton Times as a contemporary estimate and thereby most likely to be reliable but erring on the generous side), that amounted to about six or seven per cent of the overall workforce. Bearing in mind that one of its largest affiliates, the ASRS did not by and large take part in the disputes of 1890, this puts the Maritime Strike in some sort of perspective. At its height it would have barely affected most workers. At most it would have 
been something they read about in the newspapers. It may be that as a result of its having happened at all "frightened conservatives heard the tramp of workers' boots, smelt the smoke and saw the flames of socialist revolt", to quote Sinclair (1965, p. 106), but conservatives are notorious in such circumstances for seeing and hearing things that no-one else, least of all the union movement, can hear and see. That the Maritime Strike has bulked so large since has been mainly because of the inability of historians to get the smoke out of their nostrils. I would suggest that while the defeat of this strike contributed to the subsequent union pressure for the introduction of conciliation and arbitration, the main reasons for that pressure were more prosaic; an appreciation of relative industrial weakness and palpable distress among trade union members.

In my view, Holt's assessment of the significance of the Maritime Strike stands at the threshold of a reassessment of the traditional view as expounded by Sinclair and others. He accepts that in some ways it was a footnote to an Australian affair, and that Millar was no militant advocate of industrial action (which is not to say that he was no radical). But notwithstanding this he expresses surprise that there was not more picketing and attendant violence (which he apparently thinks is an inevitable accompaniment to such).

He goes on to suggest that "the possessing classes" as he describes them were not only afraid that this was a harbinger or widespread social disruption but that they were right to think so. And ultimately he suggests it was the Maritime Strike which was the crucial watershed in union consciousness between the adherence to industrial means of the achievement of objects and the rejection of this in favour of political means to the same end. That is to say he has retreated into the traditional interpretation of historical events.

What we do know is that the employer response to challenges by trade unions in this period was immediate and sharp. It was not only the maritime employers who forced humiliating terms of surrender on Miller and his friends. Any active unionist was liable to victimisation by blacklisting and even as late as 1895 the conservative Trades and Labour Councils were virtually inoperative. Organised labour both before and after 1890 was characterised by its weakness and unions needed no industrial defeat in 1890 to tell them that political activity was their only salvation. They were encouraged to this by the reappearance of the Reform Associations at the 1890 election. These were largely coalitions of landowners and employers committed to substantial cuts in social expenditure, removal of many tariff barriers to free-trading and a cessation of borrowing. They naturally also opposed the passage of factory and other industrial legislation. In response the Trades and Labour Councils, particularly in the South Island, encouraged the formation of People's Political Associations to ensure the election of candidates sympathetic to working people. These groups contributed significantly to the election of a new parliament in 1890 which provided the majority group from which was to grow a Liberal Party. Although these union-based political associations had no national policy as such, they had comprehensive notions of what they expected of the new government which took office in 1891. These included nationalisation of land, railways, mines and coastal shipping, work schemes for the unemployed, factory acts and compulsory arbitration (Sinclair, 1965). The programmes differed from centre to centre. The Wellington platform of October 1890 for instance called for repeal of the property tax; introduction of a land tax; an elective Legislative Council; leasehold tenure of crown lands; no immigrant labour; the preservation of the education system from retrenchment and the addition of a new system of technical training. In Christchurch a month earlier the programme called in addition to similar policies for labour and factory legislation (Salmond, 1950, p. 131). But all these programmes tended in the same general direction. During their first parliamentary term and into their second, these political debts were paid by the government first of Ballance and then of Seddon under the ministerial aegis of William Reeves, Minister of Justice and ultimately of Labour.

This was not as straightforward as might be imagined. The outgoing Atkinson government had stacked the Legislative Council with members sympathetic to the Reform Associations. This group for the next four years consistently opposed labour legislation. The Liberals had to convince the Colonial Office to overrule the Governor, Lord Glascow, who refused to appoint further members of the Council to balance those appointed by Atkinson before they could pass much of their programme into law. Reeves' first attempts at labour legislation were either thrown out entirely by the Legislative Council or so mutilated by them as to be virtually unrecognisable. These included shop hours, workmen's lien, truck and factory bills. There was no doubt where the opposition was coming from. Opposition MPs Buckland, Duthie and Fergus spoke for the employers associations in condemning the proposed laws as "at best meddlesome interference, at worst .... the enslavement of the people" (quoted in Sinclair, 1965, 
p. 138). Even William Rolleston, generally enlightened in matters of labour legislation at least said in parliament of these bills: "I think that they presume too much upon an antagonism of employers and employed, and too little upon the mutual understanding that ought to subsist between them." (Parliamentary Debates, 1891, 72, p. 582). Others were more forthright. The Shop Act which aimed to restrict the hours which women could be required to work degraded them and took away their liberty, said Buckland. When Reeves circulated a proposed arbitration law the opposition of employer associations was so ferocious that he did not even bother to introduce it in the House. He tried again in 1892 but his proposals for reform were simply blocked by the Legislative Council.

These proposals included an arbitration act which had two important features. There was provision for compulsory and legally binding arbitration of disputes if conciliation failed, and equally important but sometimes ignored, this process could be initiated only by registered trade unions. This not only placed a legal weapon to force settlement of disputes by third parties in the hands of unions but encouraged the formation of such associations as a first step in that process. The significance of this latter which has been misunderstood by some commentators is crucial to an understanding of the Liberal approach to industrial matters. The intention was to assist working people to help themselves by combining into collective associations, not to intervene on their behalf. The role of the state was to ensure fair play as disinterested referee. Employers who were the stronger party in industrial disputes did not see the matter in quite that light and their opposition to both aspects of the legislation was virulent and bitter. This drew an equally strong response from organised workers. In August 1892 the Wellington Trades and Labour Council reacted to the rejection of labour bills by the Legislative Council by resolving: "That this Council views with astonishment the determined hostility of the Legislative Council to labour measures as shown by the rejection of Labour members of the Council" (Samond, 1950, p. 132). Reading contemporary newspaper accounts, even allowing for the rather staid journalistic periods of the day, it is difficult not be to impressed by the heat these issues generated.

In 1893 Reeves confined himself to non-arbitral industrial legislation. In 1894, as Minister of Labour in a government returned with a thumping majority and the automatic veto of the Legislative Council largely removed, he returned to the charge in introducing his revised Industrial Conciliation and Arbitration Bill. As with his proposal of 1892 it aimed to encourage the formation of unions and to prevent strikes. This twin aim has puzzled some historians (including Sinclair in his biography of Reeves (1965), and in his other writings; but not including one of his major critics Oliver (1969), in his extremely interesting essay "Reeves, Sinclair and the Social Pattern" in which there is a very clear exposition of how those two things fit together). misled by the popular misconception that the formation of a trade union is inevitably followed by an exponential increase in industrial action. This notion that if there were no unions there would be no strikes has certainly been the orthodox ideology of employers over the succeeding century. It was not the philosophy of Reeves and the Trades and Labour Councils. On the contrary in a remark which sums up the view of both, Reeves had said of compulsory arbitration in the House in 1893 his proposal was "a kindly solution of the natural warfare between classes". In the teeth of continuing and rancorous opposition from employers, landowners and their parliamentary spokesmen, the arbitration legislation was passed. In the event and as the pattern of industrial events has shown since in New Zealand, Reeves and the Trades and Labour Councils predicted more accurately than their opponents. This has not reconciled employers (except for a brief and exceptional period between 1908 and 1913) to the philosophies of arbitration. As a coda to that one might at a pinch include the ten years or so from the mid-fifties, but I don't think so. Full employment and a constantly rising level of real incomes meant only that the issue submerged but below the surface it remained lively enough. One needs only for instance to review the battles in the state sector around the two McCarthy Commissions of 1962 and 1968 to be immediately aware of this.

Ironically the growing success of the programmes of the People's Political Associations came at the very moment at which the political consensus which had produced the election victories of 1890 and 1893 for the Liberals was breaking up and was being replaced by another which was not nearly as congenial to political initiatives on behalf of organised labour. This break was already apparent before the 1893 election at least in some centres. Salmond (p. 132) records a curious resolution passed by the Wellington Trades and Labour Council in July: "That the secretary inform the Liberal Association that its action in setting up an Electoral Committee as constituted is calculated to create a permanent schism between the Labour and Liberal parties, and that if this should occur, the Trades Council will hold the Liberal Association primarily responsible." This followed meetings between the two which had failed to 
resolve serious differences over the incorporation of labour planks in the Liberal platform for Wellington. A further effort to reach an agreed electoral platform also failed with the result that the overall Liberal vote in Wellington fell and only two Liberals were elected (although one of these was Sir Robert Stout who was to lead the left Opposition to Seddon over the next few years).

After the election the rift became more pronounced as businessmen, of whom Ward was the exemplar, came increasingly to dominate party counsels. The Auckland Star, leading Liberal daily was by 1895 editoralising against Reeves for "legislating ahead of public requirements" and this opinion was endorsed by Seddon (Sinclair 1965, p. 217). Other, less friendly newspapers weighed in, and Reeves' colleagues were in some instances openly hostile. "I am sorry to say it", one of them, Willis, said later in the same year, "but I am getting sick and tired of so much labour legislation ... I do not think this continual tinkering with labour legislation is conducive to the best interests of the colony." The Liberals were learning the fundamental lesson of New Zealand democracy; retaining power meant holding together an electoral coalition of small businessmen, small farmers and the urban petit bourgeois and this was not always compatible with the industrial needs of trades union members. From 1895 union influence on the political system entered an eclipse from which it was not to recover until the first Labour government took office in 1935 . With it went any hope of effectively protecting and consolidating the gains made at the political level between 1891 and 1894 . The period between then and 1935 is, as Holt so clearly delineates, a series of retreats for organised labour in the face of employer intransigence.

For the employers in general had never - have never - accepted as legitimate what happened between 1891 and 1894. Like the ancien regime they had learned nothing and forgotten nothing. As Sinclair (1961) has remarked of the labour legislation of the period: “The conservatives bluntly called it 'socialism'. For in two respects this legislation was what people then meant by the term. First it was primarily of benefit to employers rather than employers. and seemed to nervous capitalists to be a blow at profits. Secondly it involved a notable extension of the powers of the state".

This revanchist philosophy has informed the basis of employer initiatives since. Unless it is apprehended that the employer agenda in the century succeeding has been to roll back the union successes of the 1890s (something they still insist on labelling "socialism') then the history of industrial relations in that period is barely to be comprehended at all.

\section{References}

Hamer D A (1963) Sir Robert Stout and the labour question, 1870-1893. In Chapman R and Sinclair K (Eds) Studies of a small democracy: essays in honour of Willis Airey Auckland. Paul.

Holt J (1976) The political origins of compulsory arbitration in New Zealand. A comparison with Great Britain New Zealand Journal of History 10(2): 99-111.

Oliver W H (1969) Reeves, Sinclair and the social pattern. In Munz P (Ed) The feel of truth: essays in New Zealand and Pacific history Wellington, Reed.

Olssen E (1987) The origins of the labour party: a reconsideration New Zealand Journal of History 21(2): 79-96.

Roth B and Hammond J (1981) Toil and trouble. Auckland, Methuen.

Salmond J D (1950) New Zealand Labour's pioneering days Auckland.

Sinclair K (1961) The Liberal party's declaration 1891-1898. In Chapman R (Ed) Ends and means in New Zealand politics University of Auckland Press.

Sinclair K (1965) William Pember Reeves: New Zealand Fabian Oxford, Clarendan Press.

Sutch W B (1966(a)) The quest for security in New Zealand Wellington, Oxford University Press.

Sutch W B(1966(b)) Colony or nation? Economic crises in New Zealand from the 1860s to the 1960s: addresses and papers Sydney University Press.

Woods N S (1963) Industrial conciliation and arbitration in New Zealand Wellington. Government Printer. 